PEDAGOGISK FORSKNING I SVERIGE Vol 25 No 2-3 (2020) ISSN 1401-6788

\title{
Debatt
}

\section{Praktiknära eller uppdragsrelevant forskning?}

\author{
Claes Nilholm \\ Professor i pedagogik, Uppsala universitet \\ Kontakt: Claes.nilholm@edu.uu.se
}

Det är berömvärt att Pedagogisk Forskning i Sverige initierar en debatt om framväxten av den praktiknära forskningen. Personligen tycker jag att det är positivt att den utbildningsvetenskapliga och pedagogiska forskningens relevans för skolans utveckling fokuseras och att mer resurser satsas på en forskning som strävar efter att bidra till skolans utveckling. Därmed inte sagt att all forskning ska ha denna inriktning. Jag tror många av de skattebetalare som finansierar utbildningsvetenskaplig och pedagogisk forskning dock förväntar sig att sådan forskning ska bidra till att utveckla skolan. De skulle förmodligen bli mycket förvånade om de fann hur lätt många forskare tar på denna uppgift. Det är ofta inte forskning som strävar efter att utveckla praxis som ger mest symboliskt kapital inom akademin. I det följande kommer jag att argumentera för att det av flera skäl dock är mer fruktbart att tala om uppdragsrelevant än praktiknära forskning.

Om forskare och praktiker i samarbete ska utveckla skolan inställer sig genast frågan vad denna skola ska utvecklas till. Detta är den helt centrala frågan när det gäller skolforskningen. I vår demokrati bestäms målen av skolan av politiker och de får sitt uttryck i lagar och förordningar. Utbildningsväsendet har således ett uppdrag som ges av politiken. Det är då lätt att tänka sig att det är detta uppdrag som den praktiknära forskningen är tänkt att realisera. Här inställer sig dock en rad komplikationer: a) uppdraget är relativt vagt och otydligt formulerat i styrdokumenten, b) många lärare och politiker känner inte till uppdraget c) det offentliga samtalet om skolan handlar i huvudsak om kunskapsuppdraget och inte om det bredare uppdrag som skisseras i styrdokumenten. Situationen kompliceras ytterligare av att olika aktörer $\mathrm{i}$ utbildningsväsendet tycker att skolan ska ha ett annat uppdrag än det 
demokratiskt beslutade. För att något bringa reda i denna oreda skulle jag vilja föreslå begreppet "uppdragsrelevant forskning" i stället för "praktiknära forskning" eftersom det sätter i fokus den för utbildningen helt avgörande frågan om utbildningens mål. Det är dessa vi måste diskutera för att överhuvudtaget komma längre i diskussionen om skolan inbegripet frågan om den praktiknära forskningen.

I styrdokumenten skisseras ett brett uppdrag för skolan och det är detta som då borde stå i centrum för det skolutvecklande arbetet. Jag befarar dock och ser tecken på att den skolnära forskningen följer nära i spåren på den effektivitetsdiskurs (jfr Schiro, 2013) som dominerat samtalet om skolan och som smalnar av skolans uppdrag till att handla om endast kunskapsprestationer (alltså inte kunskapstillägnande som är något annat) (jfr också Serder \& Malmström, 2020). På så sätt kan praktiknära forskning i värsta fall bli ett sätt att underminera det demokratiskt beslutade breda uppdraget för skolan. På liknande sätt kan idén om att praktikens frågor ska vägleda forskningen också leda till en underminering av uppdraget. Som framgår av Wedins (2020) inlägg är det uppenbart att vad lärare ser som praktikrelevant långtifrån alltid är uppdragsrelevant. En liknande argumentation gäller evidensdiskussionen, där evidensen givetvis måste vara relevant $i$ relation till skolans uppdrag och inte bara fokusera på kunskapsprestationer eller någon annan isolerad aspekt av uppdraget.

För att summera det som sagts hittills menar jag att det är bra att mer forskning ägnas åt att utveckla skolors och lärares arbete men att det är viktigt att sådan utveckling ligger $i$ linje med det uppdrag som vi $i$ vår demokrati har beslutat att skolan ska ha. Utvecklingen mot en praktiknära/uppdragsrelevant forskning kan dock förväntas möte flera svårigheter och utmaningar. Några sådana diskuteras av Persson (2020) och Wedin (2020) i tidigare inlägg i debatten. Det är också oroande att så lite av diskussionen om praktiknära forskning förs utifrån den evidens som föreligger när det gäller att utveckla skolors arbete. Som vanligt i den svenska diskussionen bygger argumenten oftast på ideologiska övertygelser.

Utöver att uttrycket skolnära forskning inte sätter ljuset på skolans uppdrag är det förknippat med ytterligare ett grundläggande problem. Det bidrar nämligen till att återskapa idén att vi har teori som utvecklas i ett akademiskt sammanhang utan praktik och en praktik där det inte finns någon teori. I själv verket har akademin en praktik som är oerhört betydelsefull för vilken forskning som kommer att utvecklas där. Det som ger symboliskt kapital i akademin är ofta något helt annat än vad som kan utveckla den underliggande praktiken. På motsvarande sätt finns det teorier i praktiken vilka, till skillnad från teorier inom akademin, konstant prövas och omprövas i praxis. Med den tilltro till vetenskap och forskning som finns $i$ vårt samhälle ses de senare teorierna närmast a priori som mycket mindre värde än teorier utvecklade $i$ ett akademiskt sammanhang. Det är den här typen av tänkande jag tror vi 
måste komma förbi för att kunna utveckla den skolnära/uppdragsrelevanta forskningen. Att ändra ett uttryck är väldigt svårt om det ifrågasätter grundläggande och etablerade tankestrukturer. Min förhoppning är dock att uttrycket uppdragsrelevant ska bidra till en förändring av sådana strukturer vad gäller tänkandet om relationen mellan teori och praktik.

En sista aspekt av frågan om uppdragsrelevans berör det som brukar kallas grund- och/eller nyfikenhetsforskning. Få skulle väl hävda att en sådan forskning ska vara uppdragsrelevant i den mening som givits ovan. Dock tror jag det är viktigt att även denna forskning förhåller sig till vad som ska vara utbildningens uppdrag. Allt teoretiserande om utbildning har en ideologisk komponent och det är viktigt att göra denna explicit. I en diskussion som tar sin utgångspunkt i frågan om vad utbildningen är till för och vad forskningens roll ska vara $i$ relation till skolan ska vi inte ha vattentäta skott mellan grundforskning och uppdragsrelevant forskning.

\section{REFERENSER}

Persson Anders. (2020) Dubbel närhet och distans behövs i praktiknära forskning. Pedagogisk Forskning $i$ Sverige. [publicerat ahead of print]. https://open.lnu.se/index.php/PFS/article/view/2547/2275. [hämtad 200820]

Schiro, Michael S. (2013). Curriculum theory: Conflicting visions and enduring concerns. Thousand Oaks, CA: SAGE publications Inc.

Serder, Margareta och Malmström, Martin (2020). Vad talar vi om när vi talar om praktiknära forskning. Pedagogisk forskning i Sverige, 25(1), 106-109.

Wedin, Åsa (2020). Att hantera mindre goda exempel - dilemma för praktiknära forskning. Pedagogisk Forskning i Sverige, 25(1), 102-105. 